\title{
ANALISIS PERHITUNGAN HARGA JUAL PRODUK DENGAN DASAR HARGA POKOK PESANAN METODE FULL COSTING STUDI PADA UD. KUBE MAWAR PUTIH
}

\author{
Gendis Hardiyanti Aprilia ${ }^{1)}$ Hayuningtyas Pramesti Dewi ${ }^{2)}$ \\ Program Studi Akuntansi Fakultas Ekonomi \\ Universitas Krisnadwipayana \\ gendishardiyanti@gmail.com ${ }^{1)}$ \\ ethniz@gmail.com ${ }^{2}$
}

\begin{abstract}
This study aims to determine the product selling price based on the order price of UMKM UD. Kube Mawar Putih. Data is obtained by means of interviews and documentation studies and analyzed by comparing the calculation of the production cost which has been carried out by the company with the calculation of the cost of goods with the full costing method. The result of the study show that the difference in advantegous if the company uses the calculation of full costing method.
\end{abstract}

Keywords: Selling Price, Cost Production, Full Costing Method.

\section{PENDAHULUAN}

Pertumbuhan Unit Mikro Kecil Menangah (UMKM) di Indonesia mengalami peningkatan yang signifikan dengan jenis dan bidang usahanya yang beragam. Namun seringkali UMKM tidak dapat bertahan karena masalah internal dan eksternal. Salah satu penyebabnya adalah tidak tercapainya target tujuan perusahaan. Tujuan perusahaan secara umum adalah memperoleh keuntungan maksimal dengan biaya yang seminimal mungkin. Untuk mencapai Laba maksimal yang diinginkan, penentuan harga jual menjadi salah satu faktor yang sangat berpengaruh. Harga jual dapat mempengaruhi daya beli masyarakat yang nantinya akan berdampak pada jumlah penjualan perusahaan dan juga akan mempengaruhi Laba pada akhirnya. Dengan demikian untuk mencapai persentase Laba yang diinginkan maka perusahaan perlu menentukan harga jual yang tepat untuk produknya. Penentuan harga jual yang tepat ini menjadi salah satu masalah utama dalam UD Kube Mawar Putih, yaitu sebuah UMKM yang bergerak di bidang usaha jasa catering untuk acara-acara pernikahan, seminar-seminar,dan lainnya. Usaha yang didirikan sejak tahun 2008 ini menerapkan sistem penjualan dalam bentuk pesanan dengan berbagai kelompok menu. Sistem pembayaran yang selama ini dilakukan oleh perusahaan adalah dengan sistem pembayaran berjangka, yaitu pelanggan memberikan uang muka sebesar $25 \%$ dari total harga yang ditentukan dan melunasi sisanya setelah jasa dilakukan.
Namun dalam penentuan harga jual perusahaan tidak memperhitungkan perkiraan biaya yang akan terjadi, sehingga perusahaan sering mengalami kerugian karena biaya yang dikeluarkan ternyata melebihi pendapatan dari penjualan produk. Penelitian ini mencoba mengkalkulasi penentuan harga jual yang tepat untuk mendapatkan Laba yang maksimal dalam UD Kube Mawar Putih. Namun dengan beragamnya kelompok menu yang ditawarkan oleh perusahaan, maka penelitian hanya akan memfokuskan pada penentuan harga jual pada kelompok menu makanan kotak yang dipesan pada bulan Januari sampai dengan Februari 2018. Penentuan harga jual akan didasari dari penentuan harga pokok pesanan yang terjadi dari setiap menu makanan kotak yang dipesan. Penelitian sejalan pernah dilakukan sebelumnya oleh Irma Sari (2013) dengan hasil penelitian perhitungan harga pokok produksi menurut perusahaan untuk satu pesanan terlalu rendah sehingga menimbulkan selisih kurang bila dibandingkan dengan hasil analisis.

\section{TINJAUAN PUSTAKA}

\section{Akuntansi}

Menurut Thomas (2017:1) “Akuntansi adalah seni mengumpulkan, mengklasifikasikan, mencatat, dan menghasilkan laporan, yaitu laporan keuangan yang dapat digunakan oleh pihakpihak yang berkepentingan (stakeholder), baik pihak di dalam perusahaan atau pihak di luar perusahaan" sedangkan menurut 
American Institute of Certified Public Accountant (AICPA) dalam Faiz Zamzami dan Nabella Duta Nusa (2016:2) "Akuntansi sebagai seni pencatatan, penggolongan, dan pengikhtisaran dengan cara tertentu dan dalam ukuran moneter, transaksi dan kejadian-kejadian yang umumnya bersifat keuangan dan termasuk menafsirkan hasilhasilnya".

\section{Biaya}

Menurut Darsono (2013:19) "Biaya adalah suatu Kas atau Setara Kas yang dikorbankan untuk menghasilkan atau mendapatkan barang atau jasa yang diharapkan dapat bermanfaat atau memberikan keuntungan di masa depan". Menurut W.A Paton, dkk dalam Neneng (2013:71) biaya adalah: 1) Harga Pokok, yaitu nilai barang atau jasa yang belum ditambah atau dikurangi beban apapun, 2) Beban, yaitu segala sesuatu yang harus ditanggung, baik sebagai biaya pokok maupun biaya tambahan lainnya, 3) Rugi, yaitu penerimaan yang tidak menimbulkan tambahan, bahkan mengurangi modal. Mulyadi (2014:13) mengklasifikasikan biaya ke dalam lima macam pengelompokkan biaya, yaitu: 1) Penggolongan biaya berdasarkan objek pengeluarannya, 2) Penggolongan biaya berdasarkan fungsi pokok dalam perusahaan (Biaya Produksi, Biaya Pemasaran, Biaya Administrasi dan Umum), 3) Penggolongan biaya berdasarkan hubungan biaya dengan sesuatu yang dibiayai (Biaya Langsung, Biaya Tidak Langsung), 4) Penggolongan biaya berdasarkan perilaku biaya dalam hubungannya dengan perubahan volume kegiatan (Biaya Variabel, Biaya Semi Variabel, Biaya Semi Fixed, Biaya Tetap), 5) Penggolongan biaya berdasarkan jangka waktu manfaatnya (Capital Expenditure, Revenue Expenditure).

\section{Akuntansi Biaya}

Menurut Hamli (2014:4) "Akuntansi biaya adalah alat yang penting untuk membantu pihak manajemen dalam melakukan pertimbangan, perencanaan, pengawasan serta sebagai penilaian terhadap kegiatan perusahaan. Gaji dan upah karyawan adalah salah satu dari komponen biaya yang secara rutin dikeluarkan untuk penyelenggaraan perusahaan. Dengan sistem akuntansi yang memadai, akuntan perusahaan dapat menyediakan informasi keuangan bagi setiap tingkatan manajemen, pemilik, investor, kreditor dan pemakai laporan keuangan lain".
Sedangkan menurut Abdul Halim (2015:3) "Akuntansi biaya merupakan akuntansi yang membahas tentang penentuan harga pokok (cost) dari suatu produk yang di produksi (atau dijual di pasar), baik untuk memenuhi pesanan dan pemesan maupun untuk menjadi persediaan barang dagangan yang akan dijual". Menurut Supriyono dalam Neneng (2017:49) "Tujuan Akuntansi Biaya adalah merencanakan pengendalian biaya, menentukan harga pokok produk atau jasa yang dihasilkan perusahaan dengan tepat dan teliti, pengambilan keputusan oleh manajemen, menyajikan informasi biaya bagi manajemen untuk membantu dalam pengelolaan perusahaan".

\section{Harga Pokok Produksi}

Menurut Stanton dalam Neneng (2017:127) harga pokok produksi adalah “...value expressed in terms of dollars and cens, or any other monetary medium of exchange". Menurut Mulyadi (2014:10) "Harga Pokok Produksi merupakan pengorbanan sumber ekonomi yang dinilai dalam satuan uang yang telah terjadi dan kemungkinan akan terjadi untuk mendapatkan penghasilan". Terdapat beberapa unsur biaya yang dikeluarkan oleh perusahaan dalam memproduksi suatu produk yang nantinya akan dilakukan kegiatan pengolahan mulai dari bahan mentah menjadi produk jadi, yang biasanya disebut sebagai Biaya Produksi. Menurut Salman (2013:26) "Biaya Poduksi meliputi Biaya Bahan Baku, Biaya Tenaga Kerja, dan Biaya Overhead Pabrik". Menurut Sofia (2014:46) "Tarif Biaya Overhead Pabrik dinyatakan dengan persentase 
atau jumlah rupiah untuk setiap jam kerja langsung, jam mesin, kilogram, satuan produk dan sebagainya". Pembebanan Biaya Overhead Pabrik dibebankan kepada produk berdasarkan atas satuan produk, Biaya Bahan Baku (apabila biaya overhead pabrik yang dominan bervariasi dengan nilai bahan baku), Biaya Tenaga Kerja Langsung (jika sebagian besar elemen biaya overhead pabrik berhubungan erat dengan jumlah tenaga kerja langsung), Jam Tenaga Kerja Langsung (jika biaya overhead pabrik bervariasi dengan waktu), Jam Mesin (apabila biaya overhead pabrik bervariasi dengan waktu penggunaan mesin), Dihitung setelah tingkat kapasitas yang akan dicapai dalam periode anggaran yang telah ditentukan dan anggaran biaya overhead pabrik telah disusun. Menurut Mulyadi (2014:26) "Terdapat dua metode dalam penentuan harga pokok produksi, yaitu dengan metode Full Costing dan metode Variable Costing.

\section{Harga Pokok Pesanan}

Menurut Wiwik (2017:108) Produksi Pesanan (Job Order) adalah "kegiatan produksi yang berdasarkan kriteria pesanan untuk menghasilkan suatu produk atatu jasa yang bersifat khusus atau spesifik". Menurut Samryn (2017:90) "Harga Pokok Pesanan adalah suatu sistem yang digunakan untuk menetapkan harga pokok produk yang digunakan untuk menetapkan harga pokok produk yang digunakan dalam industri yang bekerja berdasarkan pesanan. Ada empat karakteristik pokok dalan sistem ini yaitu: 1) Banyak pesanan yang berbeda dikerjakan secara bersamaan dalam setiap periode waktu, 2) Biayabiaya dikumpulkan untuk tiap pekerjaan, 3) $\mathrm{Job}$ cost sheet merupakan dokumen kunci dalam pengendalian akumulasi biaya untuk setiap pekerjaan, 4) Harga pokok per unit produk dihitung menurut tiap pekerjaan dalam job cost sheet.

\section{Harga Jual}

Menurut Kotler dan Keller dalam Wiratna (2016:172) "Harga jual adalah sejumlah uang yang dibebankan atau ditetapkan berdasarkan suatu produk atau jasa, atau jumlah dari nilai yang ditukar konsumen atas manfaat-manfaat, karena penggunaan atas produk atau jasa tersebut." Tujuan dari penetapan harga jual adalah: 1) Kelangsungan hidup, 2) Laba sekarang maksimum, 3) Pendapatan sekarang maksimum, 4) Pertumbuhan penjualan maksimum, 5) Skimming pasar maksimum, 6) Kepemimpian mutu suatu produk. Menurut Wiratna (2016:75) terdapat tiga metode untuk menetapkan suatu harga jual, yaitu: 1) Berdasarkan Biaya (Cost Plus Pricing, Mark Up Pricing, Break Even Point) 2) Berdasarkan harga pesaing, 3) Berdasarkan permintaan.

\section{METODOLOGI PENELITIAN}

Jenis penelitian merupakan Kualitatif dengan metode analisis penjabaran data-data untuk menghitung tujuan penelitian. Data-data tersebut yaitu biaya-biaya yang dikeluarkan oleh UD Kube Mawar Putih untuk mengkalkulasi harga pokok pesanan dan menentukan harga jual. Data yang digunakan dikumpulkan dengan wawancara, observasi serta studi dokumentasi. Data dianalisis dengan metode perhitungan harga pokok pesanan dengan pendekatan Full Costing.

\section{HASIL DAN PEMBAHASAN Hasil Penelitian}

Perhitungan Harga Pokok Pesanan yang dilakukan oleh UD Kube Mawar Putih pada Bulan Januari 2018 untuk pesanan paket Nasi Kotak dengan menu Ayam Kecap, Cah Jagung dan Soun Goreng adalah sebagai berikut: 
Bahan Bakl

Tabel 1

Perhitungan Bihan Bakll

\begin{tabular}{|c|c|c|c|c|c|}
\hline \multirow[t]{2}{*}{$\begin{array}{c}\text { Nama } \\
\text { Pesnan }\end{array}$} & \multirow[t]{2}{*}{$\begin{array}{c}\text { Bahan } \\
\text { Yang } \\
\text { Dipakai }\end{array}$} & \multirow[t]{2}{*}{ Satuan } & $\begin{array}{c}\text { Hargh } \\
\text { sattuan } \\
\text { (Rp) } \\
\end{array}$ & Pemakian & $\begin{array}{l}\text { Harga } \\
(\operatorname{Rp})\end{array}$ \\
\hline & & & (1) & (2) & (1) $\mathrm{x}(2)$ \\
\hline \multirow[b]{2}{*}{$\begin{array}{l}\text { Ayam } \\
\text { Keccap }\end{array}$} & Ayall & $\mathrm{Kg}_{\mathrm{g}}$ & 36,000 & $6 \mathrm{~kg}$ & 216,000 \\
\hline & $\begin{array}{l}\text { Kexap } \\
\text { Nanis }\end{array}$ & Binghtis & 19,000 & $\begin{array}{c}\text { 1boughlis } \\
\text { (600ull) }\end{array}$ & 19.00 \\
\hline \multirow{4}{*}{$\begin{array}{l}\text { Solul } \\
\text { Gotengy }\end{array}$} & Sollin & Blaghtus & 6.000 & 3 bounghis & 18.00 \\
\hline & $\begin{array}{l}\text { Cabai } \\
\text { Merah }\end{array}$ & $\mathrm{Kg}$ & 37,000 & $3 \mathrm{~kg}$ & 111.00 \\
\hline & Kol & $\mathrm{Kg}_{\mathrm{g}}$ & 12.000 & $1 \mathrm{Kg}$ & 12.00 \\
\hline & $\begin{array}{l}\text { Kerap } \\
\text { Asiil } \\
\end{array}$ & Binglins & 15,000 & 1 blughtis & 15.01 \\
\hline \multirow{3}{*}{$\begin{array}{c}\text { Cdil } \\
\text { Jagung }\end{array}$} & $\begin{array}{l}\text { Jagumg } \\
\text { Viuda }\end{array}$ & $\mathrm{Kg}$ & 7,000 & $2 \mathrm{~kg}$ & 14.00 \\
\hline & Sarí & $\mathrm{Kg}$ & 4.000 & $3 \mathrm{~kg}$ & 1200 \\
\hline & Wortel & $\mathrm{Kg}$ & 8.000 & $2 \mathrm{~kg}$ & 16,00 \\
\hline $\begin{array}{l}\text { Iasi } \\
\text { Puthin } \\
\end{array}$ & Beras & Liter & 8.000 & 8Liter & 64.00 \\
\hline \multicolumn{2}{|c|}{ Viryad Gorelge } & Liter & 11.000 & 3 Litter & 33,000 \\
\hline \multicolumn{2}{|c|}{ Kenpulk } & $\mathrm{Kg}$ & 17,000 & $1 \mathrm{Kg}$ & 17,00 \\
\hline \multicolumn{2}{|c|}{ Jendi } & $\mathrm{Kg}$ & 7,000 & $6 \mathrm{Kg}_{\mathrm{g}}$ & 42000 \\
\hline \multicolumn{2}{|c|}{ Airkemasan Gelas } & Kardis & 22000 & 2Kadus & 44,000 \\
\hline \multicolumn{5}{|c|}{ Jumlah } & 633.000 \\
\hline
\end{tabular}

\begin{tabular}{|c|c|c|c|c|}
\hline \multicolumn{5}{|c|}{$\begin{array}{c}\text { Tabel } 2 \\
\text { Bahan Penolong }\end{array}$} \\
\hline \multirow[t]{2}{*}{$\begin{array}{c}\text { Bahan Yang } \\
\text { Digunakan }\end{array}$} & \multirow[t]{2}{*}{ Satuan } & $\begin{array}{c}\text { Harga per } \\
\text { satuan } \\
(\mathrm{Rp}) \\
\end{array}$ & Pemakaian & $\begin{array}{c}\text { Harga } \\
\text { (Rp) }\end{array}$ \\
\hline & & (1) & (2) & (1) X (2) \\
\hline Tomat & $\mathrm{Kg}$ & 15.000 & $1 \mathrm{~kg}$ & 15.000 \\
\hline $\begin{array}{l}\text { Bawang } \\
\text { Merah }\end{array}$ & $\mathrm{Kg}$ & 24.000 & $1 \mathrm{~kg}$ & 24.000 \\
\hline Bawang Putih & $\mathrm{Kg}$ & 18.000 & $1 \mathrm{~kg}$ & 18.000 \\
\hline Merica & Ons & 20.000 & $1,50 \mathrm{~ns}$ & 30.000 \\
\hline Garam & Bungkus & 3.000 & 2 bungkus & 6.000 \\
\hline Gas (3kg) & Tabung & 18.000 & 2 tabung & 36.000 \\
\hline \multicolumn{4}{|l|}{ Jumlah } & 129.000 \\
\hline
\end{tabular}

Biaya Tenaga Kerja Langsung

Tabel 3

Tenaga Kerja Langung
\begin{tabular}{|c|c|c|c|}
\hline $\begin{array}{l}\text { Tenaga } \\
\text { Kerja } \\
\text { Langsung }\end{array}$ & $\begin{array}{c}\text { Lamanya } \\
\text { Waktu Kerja }\end{array}$ & $\begin{array}{c}\text { Upah/hari } \\
(\mathrm{Rp})\end{array}$ & $\begin{array}{c}\text { Jumlah } \\
(\mathrm{Rp})\end{array}$ \\
\cline { 2 - 4 } & $(1)$ & $(2)$ & $(1) \times(2)$ \\
\hline TKL1 & 2 hari & 50.000 & 100.000 \\
\hline TKL2 & 1 hari & 15.000 & 15.000 \\
\hline Jumlah & & 115.000 \\
\hline
\end{tabular}
Sumber: UD Kube Mawar Puth

\section{Biaya Overhead Pabrik}

UD. Kube Mawar Putih dalam membebankan biaya overhead pabriknya kepada setiap produk pesanan berdasarkan persentase ditentukan tarif sebesar 50\% dari biaya bahan baku. Tarif sebesar $50 \%$ dianggap tepat untuk menutup atau menggantikan biaya overhead pabrik UD. Kube Mawar Putih di setiap pesanan produk. Maka biaya overhead pabrik yang dibebankan pada produk pesanan adalah sebagai berikut:

BOP dianggarkan

$=50 \% \times$ Biaya Bahan Baku

$=50 \% \times \mathrm{Rp} 633.000$

$=\operatorname{Rp~316.500,-~}$

\section{Harga Pokok Pesanan}

Dalam mengumpulkan harga pokok produksi suatu pesanan, UD. Kube Mawar Putih memasukkan semua unsur biaya produksi yang terdiri dari biaya bahan baku, biaya tenaga kerja langsung dan biaya overhead pabrik. Untuk biaya bahan baku yang dibebankan kepada produk dihitung pada saat pesanan selesai dikerjakan, yaitu dengan menjumlahkan seluruh pemakaian biaya bahan baku. Biaya tenaga kerja langsung dibebankan kepada produk pesanan yang telah selesai dikerjakan berdasarkan tarif biaya tenaga kerja langsung per hari. Untuk biaya overhead pabrik pembebanan biaya dihitung $50 \%$ dari jumlah biaya bahan baku.

Berdasarkan biaya yang dikeluarkan dalam setiap sekali pesanan yang telah selesai dikerjakan pada Bulan Januari 2018, harga pokok pesanan adalah sebagai berikut :

1.Biaya Bahan Baku = $\quad=\mathrm{Rp} \quad 633.000,-$ 2. Biaya Tenaga Kerja Langsun $=\mathrm{Rp} \quad 115.000,-$ 3. Biaya Overhead Pabrik $\quad=\underline{R p \quad 316.500 .-}$

\section{Penentuan Harga Jual}

Rp 1.064.500,-

Berikut perhitungan harga jual yang selama ini ditetapkan untuk 60 pesanan dengan Mark Up 
yang ditentukan sebesar 1/3 dari biaya produksi pada bulan Januari, yakni :

$$
\begin{aligned}
& \text { Biaya Produksi }=\mathrm{Rp} 1.064 .500 \\
& \text { Mark Up } \quad=1 / 3 \times \operatorname{Rp} 1.064 .500 \\
& =\operatorname{Rp} 354.833 \\
& \text { Harga Jual = Rp } 1.064 .500+R p 354.833 \\
& =\operatorname{Rp} 1.419 .333: 60 \text { (Jumlah } \\
& \text { Pesanan) } \\
& =\operatorname{Rp} 23.655 / \text { porsi }
\end{aligned}
$$

Berdasarkan perhitungan harga pokok pada bulan Januari 2018, yakni Rp 23.655, UD. Kube Mawar Putih menentapkan bahwa harga jual untuk menu pesanan berupa Ayam kecap, cah jagung soun

\begin{tabular}{|c|c|c|c|c|c|}
\hline \multicolumn{6}{|c|}{$\begin{array}{c}\text { Tabel } 4 \\
\text { Bahan Baku }\end{array}$} \\
\hline \multirow[t]{2}{*}{$\begin{array}{l}\text { Nama } \\
\text { Pesanan }\end{array}$} & \multirow[t]{2}{*}{$\begin{array}{c}\text { Bahan Yang } \\
\text { Dipakai }\end{array}$} & \multirow[t]{2}{*}{ Satuan } & $\begin{array}{l}\text { Harga } \\
\text { per } \\
\text { satuan } \\
(\mathrm{Rp})\end{array}$ & Pemakaian & $\begin{array}{l}\text { Harga } \\
(\mathrm{Rp})\end{array}$ \\
\hline & & & (1) & (2) & (1) $x(2)$ \\
\hline \multirow[b]{2}{*}{ Ayam Kecap } & Ayam & $\mathrm{Kg}$ & 36.500 & $6 \mathrm{~kg}$ & 219.000 \\
\hline & Kecap & Bungkus & 19.000 & $\begin{array}{c}1 \text { bungkus } \\
(600 \mathrm{ml})\end{array}$ & 19.000 \\
\hline \multirow{4}{*}{ Soun Goreng } & Soun & Bungkus & 6.000 & 3 bungkus & 18.000 \\
\hline & Cabai Merah & $\mathrm{Kg}$ & 37.000 & $3 \mathrm{~kg}$ & 111.000 \\
\hline & Kol & $\mathrm{Kg}$ & 12.000 & $1 \mathrm{Kg}$ & 12.000 \\
\hline & Kecap Asin & Bungkus & 15.000 & 1 bungkus & 15.000 \\
\hline \multirow{3}{*}{ Cah Jagung } & Jagung Muda & $\mathrm{Kg}$ & 7.000 & $2 \mathrm{~kg}$ & 14.000 \\
\hline & Sawi & $\mathrm{Kg}$ & 4.000 & $3 \mathrm{~kg}$ & 12.000 \\
\hline & Wortel & $\mathrm{Kg}$ & 8.000 & $2 \mathrm{~kg}$ & 16.000 \\
\hline Nasi Putih & Beras & Liter & 8.500 & 8 Liter & 68.000 \\
\hline \multicolumn{2}{|l|}{ Minyak Goreng } & Liter & 12.000 & 3 Liter & 36.000 \\
\hline \multicolumn{2}{|l|}{ Kerupuk } & $\mathrm{Kg}$ & 17.000 & $1 \mathrm{Kg}$ & 17.000 \\
\hline \multicolumn{2}{|c|}{ Jeruk } & $\mathrm{Kg}$ & 7.000 & $6 \mathrm{Kg}$ & 42.000 \\
\hline \multicolumn{2}{|c|}{ Air kemasan Gelas } & Kardus & 22.000 & 2 Kardus & 44.000 \\
\hline \multicolumn{5}{|c|}{ Jumlah } & 643.000 \\
\hline
\end{tabular}
goreng Rp 25.000 per porsi. Perhitungan Harga Pokok Pesanan yang dilakukan oleh UD Kube

\begin{tabular}{|c|c|c|c|c|}
\hline \multicolumn{5}{|c|}{$\begin{array}{c}\text { Tabel } 5 \\
\text { Bahan Penolong }\end{array}$} \\
\hline \multirow[t]{2}{*}{$\begin{array}{c}\text { Bahan } \\
\text { Yang } \\
\text { Digunakan }\end{array}$} & \multirow[t]{2}{*}{ Satuan } & $\begin{array}{c}\text { Harga per } \\
\text { satuan } \\
(\mathrm{Rp})\end{array}$ & Pemakaian & $\begin{array}{c}\text { Harga } \\
(\mathrm{Rp})\end{array}$ \\
\hline & & (1) & (2) & (1) $\times(2)$ \\
\hline Tomat & $\mathrm{Kg}$ & 16.000 & $1 \mathrm{~kg}$ & 15.000 \\
\hline $\begin{array}{l}\text { Bawang } \\
\text { Merah }\end{array}$ & $\mathrm{Kg}$ & 26.000 & $1 \mathrm{~kg}$ & 26.000 \\
\hline $\begin{array}{l}\text { Bawang } \\
\text { Putih }\end{array}$ & $\mathrm{Kg}$ & 19.000 & $1 \mathrm{~kg}$ & 19.000 \\
\hline Merica & Ons & 20.000 & $1,50 \mathrm{~ns}$ & 30.000 \\
\hline Garam & Bungkus & 3.000 & 2 bungkus & 6.000 \\
\hline Gas (3kg) & Tabung & 19.000 & 2 tabung & 38.000 \\
\hline \begin{tabular}{|l|} 
Jumlah \\
\end{tabular} & & & & 134.000 \\
\hline
\end{tabular}
Mawar Putih pada Bulan Februari 2018 untuk pesanan paket Nasi Kotak dengan menu Ayam Kecap, Cah Jagung dan Soun Goreng adalah sebagai berikut:

Sumber: UD Kube Mawar Putih
Biaya Tenaga Kerja Langsung

Tabel 6

Tenaga Kerja Langsung

\begin{tabular}{|c|c|c|c|}
\hline $\begin{array}{c}\text { Tenaga } \\
\text { Kerja } \\
\text { Langsung }\end{array}$ & $\begin{array}{c}\text { Lamanya } \\
\text { Waktu Kerja }\end{array}$ & $\begin{array}{c}\text { Upah/hari } \\
(\mathrm{Rp})\end{array}$ & $\begin{array}{c}\text { Jumlah } \\
(\mathrm{Rp})\end{array}$ \\
\cline { 2 - 4 } & $(1)$ & $(2)$ & $(1) \times(2)$ \\
\hline TKL1 & 2 hari & 50.000 & 100.000 \\
\hline TKL2 & 1 hari & 15.000 & 15.000 \\
\hline Jumlah & & 115.000 \\
\hline
\end{tabular}

Sumber: UD Kube Mawar Putih

\section{Biaya Overhead Pabrik}

UD. Kube Mawar Putih dalam membebankan biaya overhead pabriknya kepada setiap produk pesanan berdasarkan persentase ditentukan tarif sebesar $50 \%$ dari biaya bahan baku. Tarif sebesar $50 \%$ dianggap tepat untuk menutup atau menggantikan biaya overhead pabrik UD. Kube Mawar Putih disetiap pesanan produk. Maka biaya overhead pabrik yang dibebankan pada produk pesanan adalah sebagai berikut:

BOP yang dianggarkan

$=50 \% \times$ Biaya Bahan Baku

$=50 \% \times \mathrm{Rp} 643.000$

$=\operatorname{Rp} 321.500$

\section{Harga Pokok Pesanan}

Berdasarkan biaya yang dikeluarkan dalam setiap sekali pesanan yang telah selesai dikerjakan pada Bulan Februari 2018, harga pokok Pesanan Paket Makanan (Ayam Kecap, Soun Goreng dan Cah Jagung) adalah sebagai berikut:

1.Biaya Bahan Baku Produksi =Rp 643.000,2.Biaya Tenaga Kerja Langsung $=\mathrm{Rp}$ 115.000,- 


$$
\text { 3. Biaya Overhead Pabrik }=\frac{R p 321.500,-}{\operatorname{Rp} 1.079 .500,-}
$$

\section{Penentuan Harga Jual}

Berikut perhitungan harga jual yang selama ini ditetapkan untuk 60 pesanan dengan Mark Up yang ditentukan sebesar 1/3 dari Biaya Produksi pada bulan Februari, yakni :

Biaya Produksi $=\mathrm{Rp} 1.079 .500$

$$
\begin{aligned}
& \text { Mark Up } \quad=1 / 3 \times \operatorname{Rp} 1.079 .500 \\
& =\operatorname{Rp} 359.833 \\
& \text { Harga Jual } \quad=R p 1.079 .500+R p 359.833 \\
& =\mathrm{Rp} 1.439 .333: 60 \text { (Jumlah } \\
& \text { Pesanan) } \\
& =\operatorname{Rp} 23.998 / \text { porsi }
\end{aligned}
$$

Berdasarkan perhitungan harga pokok pada bulan Februari 2018, yakni Rp 23.998, UD. Kube Mawar Putih menentapkan bahwa harga jual untuk menu pesanan berupa Ayam kecap, cah jagung soun goreng $\mathrm{Rp} 25.000$ per porsi.

\section{Pembahasan}

Perhitungan Harga Pokok Pesanan yang tepat bagi UD Kube Mawar Putih

Berdasarkan analisis yang dilakukan, maka

\begin{tabular}{|c|c|c|c|}
\hline \multirow{2}{*}{$\begin{array}{c}\text { Bahan Yang } \\
\text { Dipakai }\end{array}$} & $\begin{array}{l}\text { Harga satuan } \\
\text { (Rp) }\end{array}$ & Pemakaian & $\begin{array}{l}\text { Harga } \\
\text { (Rp) }\end{array}$ \\
\hline & (1) & (2) & (1) $\mathrm{x}(2)$ \\
\hline Ayam & 36.000 & $6 \mathrm{~kg}$ & 216.000 \\
\hline Kecap & 19.000 & $\begin{array}{l}1 \text { bungkus } \\
(600 \mathrm{ml})\end{array}$ & 19.000 \\
\hline Soun & 6.000 & 3 bungkus & 18.000 \\
\hline Cabai Merah & 37.000 & $3 \mathrm{~kg}$ & 111.000 \\
\hline Kol & 12.000 & $1 \mathrm{Kg}$ & 12.000 \\
\hline Kecap Asin & 15.000 & 1 bungkus & 15.000 \\
\hline Jagung Muda & 7.000 & $2 \mathrm{~kg}$ & 14.000 \\
\hline Sawi & 4.000 & $3 \mathrm{~kg}$ & 12.000 \\
\hline Wortel & 8.000 & $2 \mathrm{~kg}$ & 16.000 \\
\hline Beras & 8.000 & 8 Liter & 64.000 \\
\hline Minyak Goreng & 11.000 & 3 Liter & 33.000 \\
\hline Kerupuk & 17.000 & $1 \mathrm{Kg}$ & 17.000 \\
\hline Jeruk & 7.000 & $6 \mathrm{Kg}$ & 42.000 \\
\hline $\begin{array}{l}\text { Air Kemasan } \\
\text { Gelas }\end{array}$ & 22.000 & 2 Kardus & 44.000 \\
\hline \multicolumn{3}{|l|}{ Jumlah } & 633.000 \\
\hline
\end{tabular}
dilakukan perhitungan harga pokok pesanan pada UD. Kube Mawar Putih menggunakan metode full costing produk paket nasi berupa ayam, Soun Goreng dan cah jagung.

\begin{tabular}{|c|c|c|c|}
\hline \multirow[t]{2}{*}{ Bahan Yang Dipakai } & $\begin{array}{l}\text { Harga per satuan } \\
\text { (Rp) }\end{array}$ & Pemakaian & $\begin{array}{c}\text { Harga } \\
\text { (Rp) }\end{array}$ \\
\hline & (1) & (2) & (1) $x(2)$ \\
\hline Ayam & 36.500 & $6 \mathrm{~kg}$ & 219.000 \\
\hline Kecap & 19.000 & $\begin{array}{c}1 \text { bungkus } \\
\text { (600ml) }\end{array}$ & 19.000 \\
\hline Soun & 6.000 & 3 bungkus & 18.000 \\
\hline Cabai Merah & 37.000 & $3 \mathrm{~kg}$ & 111.000 \\
\hline Kol & 12.000 & $1 \mathrm{Kg}$ & 12.000 \\
\hline Kecap Asin & 15.000 & 1 bungkus & 15.000 \\
\hline Jagung Muda & 7.000 & $2 \mathrm{~kg}$ & 14.000 \\
\hline Sawi & 4.000 & $3 \mathrm{~kg}$ & 12.000 \\
\hline Wortel & 8.000 & $2 \mathrm{~kg}$ & 16.000 \\
\hline Beras & 8.500 & 8 Liter & 68.000 \\
\hline Minyak Goreng & 12.000 & 3 Liter & 36.000 \\
\hline Kerupuk & 17.000 & $1 \mathrm{Kg}$ & 17.000 \\
\hline Jeruk & 7.000 & $6 \mathrm{Kg}$ & 42.000 \\
\hline Air Kemasan Gelas & 22.000 & 2 Kardus & 44.000 \\
\hline \multicolumn{3}{|l|}{ Jumlah } & 643.000 \\
\hline
\end{tabular}

\section{1) Biaya Bahan Baku}

\section{Tabel 7}

\section{Bahan Baku Bulan Januari 2018}

Sumber : Data diolah Penulis (2018)
Tabel 8

Bahan Baku Bulan Februari 2018

Sumber : Data diolah Penulis (2018)

Tabel 7 dan Tabel 8 menunjukkan bahwa Biaya bahan baku yang digunakan untuk memproduksi 60 kotak pesanan mengalami kenaikan sebesar Rp 10.000 pada bulan Januari sampai Februari, yang disebabkan oleh kenaikan Ayam dan Cabai Merah. Hal ini menyebabkan kenaikan biaya bahan baku dari Rp 633.000 menjadi Rp 643.000.

\section{2) Bahan Penolong}

\section{Tabel 9}

Bahan Penolong Bulan Januari 2018

\begin{tabular}{|l|c|c|c|r|}
\hline \multirow{2}{*}{$\begin{array}{c}\text { Bahan Yang } \\
\text { Digunakan }\end{array}$} & Satuan & $\begin{array}{c}\text { Harga per } \\
\text { satuan } \\
(\mathbf{R p})\end{array}$ & Pemakaian & $\begin{array}{c}\text { Harga } \\
(\mathbf{R p})\end{array}$ \\
\cline { 3 - 5 } & $\mathrm{Kg}$ & 15.000 & $1 \mathrm{~kg}$ & 15.000 \\
\hline Tomat & $\mathrm{Kg}$ & 24.000 & $1 \mathrm{~kg}$ & 24.000 \\
\hline $\begin{array}{l}\text { Bawang } \\
\text { Merah }\end{array}$ & $\mathrm{Kg}$ & 18.000 & $1 \mathrm{~kg}$ & 18.000 \\
\hline Bawang Putih & $\mathrm{Kg}$ & 20.000 & 1,5 Ons & 30.000 \\
\hline Merica & Ons & 3.000 & 2 bungkus & 6.000 \\
\hline Garam & Bungkus & 18.000 & 2 tabung & 36.000 \\
\hline Gas (3kg) & Tabung & \multicolumn{5}{|l}{} & $\mathbf{1 2 9 . 0 0 0}$ \\
\hline Jumlah
\end{tabular}

Sumber : Data diolah Penulis (2018) 
Tabel 10

Bahan Penolong Bulan Februari 2018

\begin{tabular}{|c|c|r|c|c|}
\hline $\begin{array}{c}\text { Bahan } \\
\text { Yang } \\
\text { Digunakan }\end{array}$ & \multirow{2}{*}{ Satuan } & $\begin{array}{c}\text { Harga per } \\
\text { satuan } \\
(\mathbf{R p})\end{array}$ & Pemakaian & \multicolumn{1}{c|}{$\begin{array}{c}\text { Harga } \\
\text { (Rp) }\end{array}$} \\
\cline { 3 - 5 } & \multicolumn{1}{c|}{$(1)$} & $(2)$ & $(1) \times(2)$ \\
\hline Tomat & $\mathrm{Kg}$ & 16.000 & $1 \mathrm{~kg}$ & 15.000 \\
\hline $\begin{array}{c}\text { Bawang } \\
\text { Merah }\end{array}$ & $\mathrm{Kg}$ & 26.000 & $1 \mathrm{~kg}$ & 26.000 \\
\hline $\begin{array}{c}\text { Bawang } \\
\text { Puth }\end{array}$ & $\mathrm{Kg}$ & 19.000 & $1 \mathrm{~kg}$ & 19.000 \\
\hline Merica & Ons & 20.000 & 1,5 0ns & 30.000 \\
\hline Garam & Bungkus & 3.000 & 2 bungkus & 6.000 \\
\hline Gas (3kg) & Tabung & 19.000 & 2 tabung & 38.000 \\
\hline Jumlah & \multicolumn{3}{|l}{} & 134.000 \\
\hline
\end{tabular}

Sumber : Data diolah Penulis (2018)

Tabel 9 dan Tabel 10 menunjukkan bahwa Biaya bahan penolong yang digunakan untuk memproduksi 60 kotak pesanan mengalami kenaikan harga dari bulan Januari dan Februari, yang disebabkan oleh kenaikan Bawang merah, Bawang Putih, Tomat dan Tabung Gas $3 \mathrm{Kg}$. Hal ini menyebabkan kenaikan biaya dari Rp 129.000 menjadi Rp 134.000.

\section{3) Biaya Tenaga Kerja Langsung}

Tabel 11

Tenaga Kerja Langsung Bulan Januari 2018

\begin{tabular}{|c|c|c|c|}
\hline \multirow{2}{*}{$\begin{array}{c}\text { Tenaga Kerja } \\
\text { Langsung }\end{array}$} & $\begin{array}{c}\text { Lamanya } \\
\text { Waktu Kerja }\end{array}$ & $\begin{array}{c}\text { Upah/hari } \\
(\mathrm{Rp})\end{array}$ & $\begin{array}{c}\text { Jumlah } \\
(\mathrm{Rp})\end{array}$ \\
\cline { 2 - 4 } & $(1)$ & $(2)$ & $(1) \times(2)$ \\
\hline TKL1 & 2 hari & 50.000 & 100.000 \\
\hline TKL2 & 1 hari & 15.000 & 15.000 \\
\hline Jumlah & & 115.000 \\
\hline
\end{tabular}

Sumber : Data diolah Penulis (2018)

Tabel 12

Tenaga Kerja Langsung Bulan Februari 2018

\begin{tabular}{|c|c|c|c|}
\hline \multirow{2}{*}{$\begin{array}{l}\text { Tenaga Kerja } \\
\text { Langsung }\end{array}$} & $\begin{array}{c}\text { Lamanya } \\
\text { Waktu Kerja }\end{array}$ & $\begin{array}{c}\text { Upah/hari } \\
\text { (Rp) }\end{array}$ & $\begin{array}{c}\text { Jumlah } \\
\text { (Rp) }\end{array}$ \\
\hline & (1) & (2) & (1) $\times(2)$ \\
\hline TKL 1 & 2 hari & 50.000 & 100.000 \\
\hline TKL2 & 1 hari & 15.000 & 15.000 \\
\hline \multicolumn{3}{|l|}{ Jumlah } & 115.000 \\
\hline
\end{tabular}

Tabel 11 dan Tabel 12 menunjukkan bahwa biaya yang dikeluarkan untuk tenaga kerja langsung pada bulan Januari dan Februari tidak mengalami perubahan, dimana TKL 1 bekerja dalam waktu dua hari dengan upah Rp 50.000/hari dan TKL 2 bekerja dalam waktu satu hari dengan upah Rp15.000/hari.

\section{1) Biaya Overhead Variabel Pabrik}

Biaya Overhead Variabel pada UD. Kube Mawar Putih pada bulan Januari - Februari dimana terdiri dari biaya bahan penolong, biaya listrik, biaya kertas dan tinta, serta biaya air yang digunakan selama 2 hari dalam memproduksi 60 pesanan. Berikut rincian biaya overhead variabel yang terjadi sesungguhnya selama proses produksi pesanan :

\section{a. Biaya Listrik}

\section{Tabel 13}

Biaya Listrik Bulan Januari 2018

\begin{tabular}{|l|l|}
\hline \multicolumn{1}{|c|}{ Keterangan } & \multicolumn{1}{c|}{ Jumlah } \\
\hline Biaya Listrik Tiap Bulan & Rp 700.000 \\
\hline Biaya Listrik Perhari & Rp 700.000/31= Rp 22.580 \\
\hline Biaya Listrik Selama2 Hari Pemakaian & Rp 22.580 x 2 = Rp 45.160 \\
\hline
\end{tabular}

Sumber : Data Diolah Penulis (2018)

Tabel 14

Biaya Listrik Bulan Februari 2018

\begin{tabular}{|l|l|}
\hline \multicolumn{1}{|c|}{ Keterangan } & \multicolumn{1}{c|}{ Jumlah } \\
\hline Biaya Listrik Tiap Bullan & Rp700.000 \\
\hline Biaya Listrik Perhari & Rp700.000128=Rp 25.000 \\
\hline Biaya Listrik Selama 2HariPemakian & Rp 25.000 x 2 =Rp 50.000 \\
\hline
\end{tabular}

Sumber : Data Diolah Penulis (2018)

Tabel 13 dan Tabel 14 menunjukkan bahwa biaya listrik perhari mengalami kenaikan, karena berdasarkan jumlah hari pada bulan Januari dan Bulan Februari berbeda. Selama dua hari Kube Mawar Putih memproduksi 60 pesanan berupa ayam kecap, Soun Goreng, cah jagung. Pada bulan Januari biaya listrik yang dikeluarkan sebesar Rp 45.160, sedangkan pada bulan Februari Rp 50.000. 


\section{b. Biaya Air}

Tabel 15

BiayaAir Bulan Januari 2018

\begin{tabular}{|l|l|}
\hline \multicolumn{1}{|c|}{ Keterangan } & \multicolumn{1}{c|}{ Jumlah } \\
\hline Biaya Air Tiap Bulan & Rp 100.000 \\
\hline Biaya Air Perhari & Rp 100.000/31= Rp 3.226 \\
\hline $\begin{array}{l}\text { Biaya Air Selama 2 Hari } \\
\text { Pemakaian }\end{array}$ & Rp 3.226 x 2=Rp6.542 \\
\hline
\end{tabular}

Sumber : Data Diolah Penulis (2018)

Tabel 16

Biaya Air Bulan Februari 2018

\begin{tabular}{|l|l|}
\hline \multicolumn{1}{|c|}{ Keterangan } & \multicolumn{1}{c|}{ Jumlah } \\
\hline Biaya Listrik Tiap Bulan & Rp 100.000 \\
\hline Biaya Listrik Perhari & $\operatorname{Rp~100.000/28=Rp~3.571~}$ \\
\hline $\begin{array}{l}\text { Biaya Listrik Selama 2 Hari } \\
\text { Pemakaian }\end{array}$ & $\operatorname{Rp~3.571~x~2=Rp~7.142~}$ \\
\hline
\end{tabular}

Sumber : Data Diolah Penulis (2018)

Tabel 15 dan Tabel 16 menunjukkan bahwa biaya air perhari mengalami kenaikan, karena berdasarkan jumlah hari pada bulan Januari dan Bulan Februari berbeda. Selama dua hari Kube Mawar Putih memproduksi 60 pesanan berupa ayam kecap, Soun Goreng, cah jagung. Pada bulan Januari biaya air yang dikeluarkan sebesar Rp 6.542, sedangkan pada bulan Februari Rp 7.142 .

\section{c. Biaya Perlengkapan}

Tabel 17

\section{Biaya Perlengkapan}

\begin{tabular}{|c|c|c|}
\hline Keterangan & $\begin{array}{c}\text { Harga } \\
(\mathrm{Rp})\end{array}$ & $\begin{array}{l}\text { Harga /60 kotak } \\
\text { (Rp) }\end{array}$ \\
\hline $\begin{array}{l}\text { Set Kotak } \\
\text { Nasi }\end{array}$ & Rp 2.500/set & Rp 150.000 \\
\hline ATK & Rp 150.000/bulan & Rp $\quad 2.500$ \\
\hline Buku Nota & Rp 120.000/bulan & $\begin{array}{ll}\mathrm{Rp} & 1.200 \\
\end{array}$ \\
\hline $\begin{array}{l}\text { Plastik } \\
\text { Kerupuk }\end{array}$ & Rp 10.000/bungkus & $\mathrm{Rp}$ \\
\hline $\begin{array}{l}\text { Lampu } 18 \\
\text { watt }\end{array}$ & $\begin{array}{l}\text { Rp 105.000/setahun } \\
\text { Rp 8.750/bulan }\end{array}$ & 145 \\
\hline Jumlah & & Rp 154.012 \\
\hline
\end{tabular}

Tabel 17 menunjukkan bahwa biaya perlengkapan yang dikeluarkan untuk memproduksi 60 kotak pesanan berupa ayam kecap, cah jagung dan Soun Goreng adalah sebesar Rp 154.012.
Tabel 18 Biaya Overhead Pabrik

\begin{tabular}{|l|c|c|}
\hline \multicolumn{1}{|c|}{ Jenis Biaya } & $\begin{array}{c}\text { Jumlah } \\
\text { (Januari) }\end{array}$ & $\begin{array}{c}\text { Jumlah } \\
\text { (Februari) }\end{array}$ \\
\hline Biaya Bahan Penolong & Rp 129.000 & Rp 134.000 \\
\hline Biaya Listrik & Rp 45.160 & Rp 50.000 \\
\hline Biaya Perlengkapan & Rp 154.012 & Rp 154.012 \\
\hline Biaya Air & Rp 6.542 & Rp 7.142 \\
\hline Jumlah & Rp 334.714 & Rp 345.154 \\
\hline
\end{tabular}

Tabel 18 menunjukkan bahwa biaya overhead variabel mengalami kenaikan, karena berdasarkan jumlah hari pada bulan Januari dan Bulan Februari berbeda. Selama dua hari Kube Mawar Putih memproduksi 60 pesanan berupa ayam kecap, Soun Goreng, cah jagung. Pada bulan Januari biaya overhead variabel yang dikeluarkan sebesar Rp 334.714, sedangkan pada bulan Februari Rp 345.154.

\section{4) Biaya Overhead tetap Pabrik}

Biaya Overhead tetap pada UD. Kube Mawar Putih merupakan Aset Tetap berupa peralatan yang digunakan untuk memproduksi pesanan, yang belum disusutkan sebesar Rp 15.000.000,-. Tabel 19 menunjukkan peralatan yang dimiliki oleh UD. Kube Mawar Putih mengalami penyusutan karena digunakan untuk produksi setiap pesanan nasi box. Penyusutan tersebut akan menyebabkan tambahan biaya. Perhitungan biaya penyusutan dilakukan dengan metode garis lurus atau berdasarkan nilai ekonomis, namun dijadikan dalam satu akun yakni peralatan dikarenakan nilai sisa tidak diketahui.

Penyusutan Peralatan dihitung sebagai berikut:

Penyusutan $=\frac{\text { Harga Perolehan }}{\text { Umur Ekonomis }}$

$$
\begin{aligned}
\text { Penyusutan }= & \frac{15.000 .000}{4 \text { tahun }} \\
& =\operatorname{Rp} 3.750 .000,-/ \text { tahun }
\end{aligned}
$$

Perhitungan Penyusutan Peralatan yang dibebankan berdasarkan pesanan adalah sebagai berikut: 
Tabel 19

Penyusutan Peralatan

\begin{tabular}{|c|c|c|c|}
\hline Keterangan & Penyusutan/Tahun & Penyusutan/Bulan & $\begin{array}{c}\text { Penyusutan/60 } \\
\text { kotak }\end{array}$ \\
\hline $\begin{array}{c}\text { Penyusutan } \\
\text { Peralatan }\end{array}$ & Rp3.750.000 & Rp 250.000 & Rp4.167 \\
\hline
\end{tabular}

5) Perhitungan Full Costing

Tabel 20

Perhitungan Harga Pokok Pesanan dengan Full Costing Bulan Januari 2018

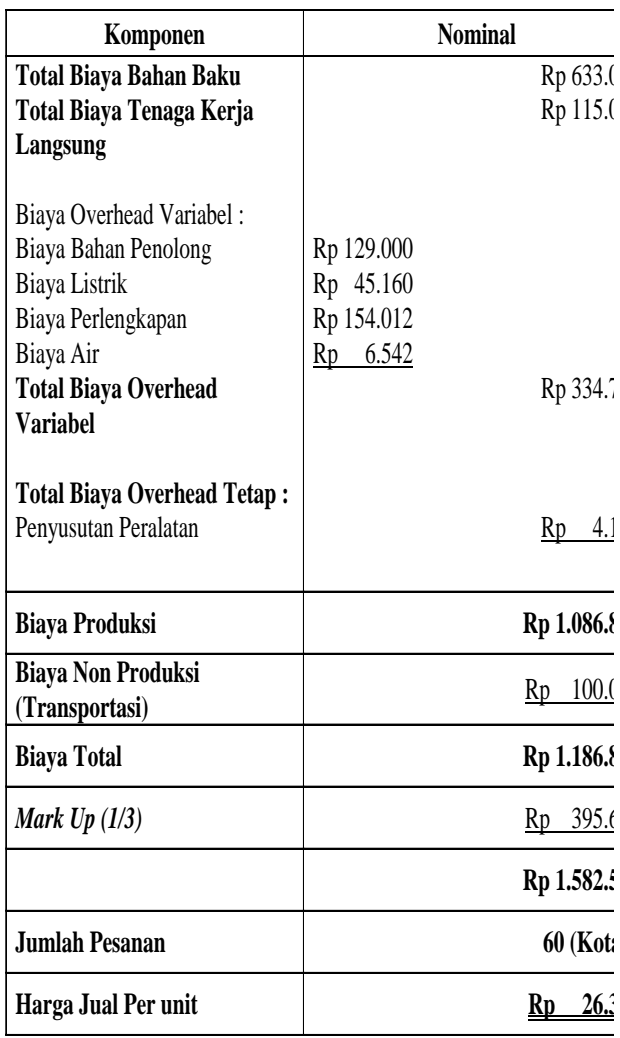

Sumber: Data Diolah Penulis (2018)
Tabel 21

Perhitungan Harga Pokok Pesanan dengan Full Costing Bulan Februari 2018

\begin{tabular}{|l|lr|}
\hline \multicolumn{1}{|c|}{ Komponen } & \multicolumn{2}{|c|}{ Nominal } \\
\hline $\begin{array}{l}\text { Total Biaya Bahan Baku } \\
\text { Total Biaya Tenaga Kerja } \\
\text { Langsung }\end{array}$ & Rp 115.000 \\
Biaya Overhead Variabel : \\
$\begin{array}{l}\text { Biaya Bahan Penolong } \\
\text { Biaya Listrik } \\
\text { Biaya Perlengkapan } \\
\text { Biaya Air } \\
\text { Total Biaya 0verhead } \\
\text { Variabel }\end{array}$ & $\begin{array}{l}\text { Rp 134.000 } \\
\text { Rp 50.000 } \\
\text { Rp 154.012 } \\
\text { Rp 7.142 }\end{array}$ \\
Total Biaya 0verhead Tetap : \\
Penyusutan Peralatan
\end{tabular}

Perbedaan Hasil Perhitungan Harga Pokok Pesanan Yang Tepat Bagi UD. Kube Mawar Putih

Berdasarkan hasil perhitungan dapat diketahui bahwa terdapat perbedaan harga pokok pesanan berdasarkan perhitungan yang diterapkan UD. Kube Mawar Putih dengan hasil analisis. Perbedaan perhitungan pembebanan tersebut mengakibatkan adanya perbedaan pula pada keputusan manajemen dalam menentukan harga jual. Pada intinya, perbedaan hasil perhitungan hanya terletak pada pembebanan biaya overhead pabrik. Berikut disajikan perbedaan perhitungan UD. Kube Mawar Putih dengan hasil analisis.

a. Perbedaan Hasil Perhitungan Biaya Overhead Pabrik berdasarkan Perhitungan Perusahaan dan Hasil Analisis 
Tabel 22

Perbedaan Biaya Overhead Pabrik Bulan Januari 2018

\begin{tabular}{|c|c|c|c|}
\hline \multirow{2}{*}{$\begin{array}{c}\text { Nama } \\
\text { Pesanan }\end{array}$} & \multicolumn{2}{|c|}{ Biaya 0verhead Pabrik } & \multirow{2}{*}{ Selisih } \\
\cline { 2 - 3 } & $\begin{array}{c}\text { UD. Kube Mawar } \\
\text { Putih }\end{array}$ & Hasil Analisis & \\
\hline $\begin{array}{c}\text { Paket } \\
\text { Ayam } \\
\text { Kecap }\end{array}$ & Rp 316.500 & Rp 338.881 & Rp 22.381 \\
\hline
\end{tabular}

Sumber: Data Diolah Penulis (2018)

Tabel 23

Perbedaan Biaya Overhead Pabrik Bulan Februari 2018

\begin{tabular}{|c|c|c|c|}
\hline \multirow{2}{*}{$\begin{array}{c}\text { Nama } \\
\text { Pesanan }\end{array}$} & \multicolumn{2}{|c|}{ Biaya 0verhead Pabrik } & \multirow{2}{*}{ Selisih } \\
\cline { 2 - 3 } & UD. Kube Mawar Putih & Hasil Analisis & \\
\hline Paket & Rp 321.500 & Rp 349.321 & \multirow{2}{*}{ Rp 27.821 } \\
Ayam & & & \\
Kecap & & & \\
\hline
\end{tabular}

Sumber: Data Diolah Penulis (2018)

b. Perbedaan Hasil Perhitungan Harga Pokok Pesanan berdasarkan Perhitungan Perusahaan dan Hasil Analisis

Tabel 24

Perbedaan Biaya Overhead Pabrik Bulan Januari 2018

\begin{tabular}{|c|c|c|c|}
\hline \multirow{2}{*}{$\begin{array}{c}\text { Nama } \\
\text { Pesanan }\end{array}$} & \multicolumn{2}{|c|}{ Harga Pokok Pesanan } & \multirow{2}{*}{ Selisih } \\
\cline { 2 - 3 } & $\begin{array}{c}\text { UD. Kube } \\
\text { Mawar Putih }\end{array}$ & Hasil Analisis & \\
\hline $\begin{array}{c}\text { Paket Ayam } \\
\text { Kecap }\end{array}$ & Rp 1.064.500 & Rp 1.086.881 & \multirow{2}{*}{ Rp 22.381 } \\
\hline
\end{tabular}

Sumber: Data Diolah Penulis (2018)

Tabel 25

Perbedaan Biaya Overhead Pabrik Bulan Februari 2018

\begin{tabular}{|c|c|c|c|}
\hline \multirow{2}{*}{$\begin{array}{c}\text { Nama } \\
\text { Pesanan }\end{array}$} & \multicolumn{2}{|c|}{ Harga Pokok Pesanan } & \multirow{2}{*}{ Selisih } \\
\cline { 2 - 3 } & $\begin{array}{c}\text { UD. Kube } \\
\text { Mawar Putih }\end{array}$ & Hasil Analisis & \\
\hline $\begin{array}{c}\text { Paket Ayam } \\
\text { Kecap }\end{array}$ & Rp 1.079.500 & Rp 1.107.321 & Rp 27.821 \\
\hline
\end{tabular}

Sumber: Data Diolah Penulis (2018)
Dari tabel diatas dapat disimpulkan bahwa selisih biaya overhead pabrik untuk pesanan, UD. Kube Mawar Putih membebankan sebesar 50\% dari biaya bahan baku yang diperoleh dari pertimbangan praktis saja tanpa ada perhitungan dan dianggap sesuai untuk menutup biaya overhead pabrik setiap pesanan. Sedangkan menurut metode analisis harga pokok pesanan untuk pembebanan biaya overhead pabrik kepada produk pesanan harus dilakukan secara teliti dan terlebih dahulu perlu di susun anggaran biaya overhead pabrik oleh perusahaan atau dengan cara mengumpulkan biaya overhead pabrik sesungguhnya setelah proses produksi selesai. Berdasarkan hasil analisis, diketahui bahwa selisih yang cukup signifikan antara biaya overhead pabrik yang harus dibebankan dan harga pokok pesanan pada setiap pesanan dengan yang diterapkan oleh perusahaan selama ini adalah sebesar Rp 22.381 pada bulan Januari dan Rp 27.821 pada bulan Februari. Hal ini karena dengan menggunakan metode full costing semua biaya dirinci secara jelas, baik itu biaya bahan baku, biaya tenaga kerja, dan biaya overhead pabrik. Sedangkan pada perhitungan harga pokok pesanan yang dilakukan UD. Kube Mawar Putih tidak memasukkan biaya overhead pabrik secara rinci ke dalam biaya produksinya. UD. Kube Mawar Putih hanya merinci biaya bahan baku, biaya tenaga kerja dan biaya overhead pabrik variabel. Karena itu, perhitungan biaya produksi UD. Kube Mawar Putih lebih kecil dibandingkan dengan menggunakan metode full costing.

\section{KESIMPULAN}

Perhitungan harga pokok pesanan yang dilakukan oleh UD Kube Mawar Puth belum mencerminkan pembebanan yang sesungguhnya terutama dalam pembebanan overhead pabrik yang dilakukan adalah sebesar 50\% dari biaya bahan baku yang diperoleh dari pertimbangan praktis saja dan dianggap sesuai untuk menutup biaya overhead pabrik setiap pesanan, serta belum menyertakan perhitungan biaya transportasi dan biaya penyusutan peralatan, sehingga menimbulkan perbedaan yang 
signifikan antara perhitungan yang dilakukan UD. Kube Mawar Putih dengan perhitungan sesuai metode analisis, yakni full costing. Sedangkan perhitungan harga jual yang selama ini diterapkan oleh UD. Kube Mawar Putih menetapkan harga jual berdasarkan harga pesaing dan belum berjalan sesuai dengan harga pokok pesanan yang semestinya. Dikarenakan belum termasuk dengan biaya-biaya yang terkait dalam harga pokok pesanan seperti pemakaian biaya bahan baku, dan bahan penolong yang mengalami perubahan tarif

Saran

UD. Kube Mawar Putih sebaiknya memperhitungkan seluruh unsur-unsur biaya overhead pabrik, biaya transportasi serta biaya penyusutan peralatan, sehingga perhitungan harga pokok pesanan dapat menggambarkan total biaya-biaya produksi yang sesungguhnya atau biaya yang lebih akurat dan dapat dijadikan dasar acuan dalam penetapan harga jual di pasaran. Dan disarankan UD. Kube Mawar Putih untuk menekan biaya produksi dapat merubah harga yang disesuaikan dengan metode perhitungan biaya-biaya yang digunakan, sehingga diharapkan ada peningkatan laba atau keuntungan dalam setiap pesanannya. Hal ini juga dapat membantu perputaran operasional keuangan UD. Kube Mawar Putih.

\section{DAFTAR PUSTAKA}

Abdul, Halim, 2015, Dasar-dasar Akuntansi Biaya, Edisi Keempat, Cetakan ketiga, Yogyakarta : BPFE-Universitas Gadjah Mada

Abdi Bhayangkara \& Meliza Putriyanti Zifi, 2016, Perhitungan Harga Pokok Pesanan Untuk Menetapkan Harga Jual (Studi Kasus Pada Usaha Riau Alumunium), Jurnal Akuntansi Keuangan dan Bisnis Vol.9, Politeknik Caltex Riau

Baldric, Siregar, dkk, 2013, Akuntansi Biaya, Jakarta: Salemba Empat

Basu, Swastha \& Ibnu Sukotjo, 2013, Pengantar Bisnis Modern (Pengantar Ekonomi
Perusahaan Modern), Edisi 3. Cetakan Kedelapan. Yogyakarta: Liberty

Carter, William K, 2013, Cost Accounting. Akuntansi Biaya, Jakarta: Salemba Empat

Darsono, Prawinegoro \& Ari, 2013, Akuntansi Manajemen, Edisi 3 Revisi, Jakarta: Mitra Wacana Media

Fachmi Pachlevi, 2017, Analisis Perhitungan

Harga Pokok Pesanan Pada

Perusahaan Fortuna Meubel, Jurnal

Fakultas Ekonomi, Universitas

Mulawarman, Vol. 9 No. 2

Faiz, Zamzani \& Nabella, 2016, Pengantar

Akuntansi I, Yogyakarta: Gadjah Mada University Press

Hamli, Syaifullah, 2014. Buku Praktis Akuntansi Biaya \& Keuangan, Jakarta: Laskar Aksara

Hery, 2015, Pengantar Akuntansi. Comprehensive Edition, Jakarta: PT. Grasindo

Hery, 2017, Teori Akuntansi : Pendekatan Konsep dan Analisis, Jakarta: PT. Grasindo

Irma Sari, dkk, 2013, Analisis Perhitungan

Harga Pokok Pesanan Meubel Dengan Metode Full Costing Pada CV Sarana Interior Di Samarinda, Jurnal Fakultas Ekonomi dan Bisnis, Universitas Mulawarman, Vol.1 No.1

Kamaruddin, Ahmad, 2015, Akuntansi Manajemen : Dasar-dasar Konsep Biaya dan Pengambilan Keputusan, Cetakan 10, Depok : Rajagrafindo Persada

Kautsar Riza, Salman, 2013, Akuntansi Biaya : Pendekatan Product Costing, Jakarta : Indeks 
L.M, Samryn, 2017, Akuntansi Manajemen. Informasi Biaya untuk Mengendalikan Aktivitas Operasi \& Investasi, Edisi Revisi, Jakarta: Prenada Media Grup

Mahmud, Hanafi \& Abdul Halim, 2016, Analisis Laporan Keuangan, Edisi Kelima, Yogyakarta: UPP STIM YKPN

Mulyadi, 2014, Akuntansi Biaya, Edisi Kelima, Cetakan Ke-12, Yogyakarta: UPP STIM YKPN

Neneng, Hartanti \& H. Rachmad, 2017, Akuntansi Biaya, Bandung: Pustaka Setia

Sri Rahayu, 2013, Analisis Perhitungan Harga Pokok Produksi Dan Pengelolaan Modal Kerja Pada Katering Sehati, Skripsi Fakultas Ekonomi dan Manajemen, Institut Pertanian Bogor

Sofia Prima \& Septian Bayu, 2017, Akuntansi Biaya. Edisi 2. Bogor: IN MEDIA

Suryani \& Hendryadi, 2016, Metode Riset Kuantitatif : Teori dan Aplikasi Pada Penelitian Bidang Manajemen dan Ekonomi Islam. Cetakan kedua. Jakarta: Prenadamedia Grup

Suwardjono, 2013, Teori Akuntansi : Perekayasaan Pelaporan Keuangan, Yogyakarta : BPFE - Universitas Gadjah Mada

Thomas, Sumarsan, 2017, Sistem Pengendalian Manajemen : Konsep, Aplikasi, dan Pengukuran Kinerja, Jakarta: PT. Indeks

V. Wiratna, Sujarweni, 2015, Metodologi Penelitian Bisnis \& Bisnis, Cetakan Pertama. Yogyakarta: Pustaka Baru Press

V. Wiratna, Sujarweni, 2015, Akuntansi Biaya Teori dan Aplikasinya, Yogyakarta: Pustaka Baru Press
V. Wiratna, Sujarweni, 2016, Akuntansi Manajemen Teori dan Aplikasinya, Yogyakarta: Pustaka Baru Press

Wiwik, Lestari \& Dhyka Bagus, 2017, Akuntansi Biaya dalam Perspektif Manajerial, Depok: PT. Rajagrafindo Persada 

